\title{
THE CONTRIBUTION OF ABU YUSUF'S THOUGHT: ISLAMIC ECONOMIC LAW RENEWAL IN THE PUBLIC FINANCE
}

\author{
Rahmaeni Nur \\ Temporary Lecturer at State Islamic Institute of Bone \\ Email: rahmawtp@gmail.com
}

\begin{abstract}
This paper will specifically examine the economic legal thought of Abu Yusuf, especially in terms of Islamic public financial management. This problem is raised because it is based on the need for a reference in managing a country's finances so that a balance of economic fundamentals can occur. Management of public finances such as tax sometimes becomes a difficult problem to solve. Especially in Indonesia, what often appears is sometimes taxpayersmanipulate tax reports plus extortion from certain parties that provide guarantees to be free from legal cases. The data source in this study is the book of al-kharaj by Abu Yusuf as primary data. The style of study used is adab al mashlahah al-mu'tabarah wa al-iqtishâd. Contextualizing the current economic reality. The findings in this study indicate that the economic thinking of Abu Yusuf prioritizes the concept of the benefit of the Ummah. The management of public finances, both concerning revenue and expenditure, the government must think about the benefit of the people. Financial management by promoting justice and balance. The implication of the findings of this study is that the management of state finances must be based on the benefit of the citizens. The indicator of all State money management is the welfare of the people. So the government in every program, must think and prioritize the benefit.
\end{abstract}

Tulisan ini secara khusus akan mengkaji tentang pemikiran hukum ekonomi Abu Yusuf khususnya dalam hal pengelolaan keuangan publik Islam. Masalah ini diangkat karena didasarkan pada kebutuhan terhadap suatu acuan dalam mengelola keuangan suatu negara sehingga dapat terjadi keseimbangan fundamental perekonomian. Pengelolaan keuangan publik semisal pajak terkadang menjadi masalah yang sulit terpecahkan. Terutama di Indonesia, hal yang sering tampak adalah terkadang wajib pajak (tax payer) memanipulasi laporan pajak ditambah lagi adanya pemerasan dari pihak-pihak tertentu yang memberikan jaminan agar terbebas dari kasus hukum. Sumber data dalam kajian ini adalah kitab al-kharaj karangan Abu Yusuf sebagai data primer. Corak kajian yang digunakan adalah adab al mashlahah al-mu'tabarah wa al-'iqtishâd. Melakukan kontekstualisasi dalam realitas perekonomian di masa sekarang ini. Temuan dalam kajian ini menunjukkan bahwa pemikiran ekonomi Abu Yusuf mengutamakan konsep kemashlahatan ummat. Pengelolaan keuangan publik, baik yang menyangkut penerimaan (revenue) maupun pengeluaran (expenditure), pemerintah harus 
memikirkan kemashlahatan rakyat. Pengelolaan keuangan dengan mengedepankan keadilan dan keseimbangan. Implikasi dari temuan penelitian ini bahwa dalam pengelolaan keuangan Negara harus didasarkan pada kemaslahatan masyarakat. Indikator dari semua pengelolaan uang Negara adalah mensejahterahkan rakyat. Maka pemerintah dalam setiap program, harus memikiran dan mengedepankan kemaslatan.

Keywords: Renewal; Abu Yusuf, Public Finance.

\section{INTRODUCTION}

A government in a country indeed has certain arrangements in terms of financial management. As we know that the success of a country can be measured by the level of prosperity of its people. People can be said to be prosperous if their needs are met, both micro and macro in nature. Micro needs involve the personal needs of an individual, while macro needs are universal.

In conventional economics, the government has many ways to raise funds to finance the running of the government. Among them are opening a business by establishing a State-Owned Enterprise (BUMN). Collect taxes such as sales tax, land tax, building and other sources. ${ }^{1}$ The government does various methods in an effort to increase state revenue, through various business products.

Islam as a religion, has the tools to guarantee its people and improve the economy. The state has legalized Islamic financial products, such as Islamic bank financing as a medium in providing financing to the public as an effort to prosper the citizens, ${ }^{2}$ in addition to the tax from financing efforts to state income.

The government in carrying out the mandate assigned to it in managing the people requires sources of income. The people or public are obliged to take care of their benefit by the authorities. According to Islam, a ruler in an ambivalence is essentially a public servant. ${ }^{3}$ The government can intervene in the private affairs of the citizens both related to the economy, society and others, which are considered to create values of overall justice. The intervention of mastery may have to remain in line with the values of the maslahat, and not violate the maqasid al-shariah. This consideration is based on the rule "tasarrufu alimami ala arra'iyati manutun

\footnotetext{
${ }^{1}$ Nurul Huda and Ahmad Muti, KeuanganPublikIslami: Pendekatan Al-Kharaj (Imam Abu Yusuf) (1 ${ }^{\text {st }}$ Ed.; Bogor: Ghalia Indonesia, 2011), p. 135.

${ }^{2}$ Annisa MasruriZaimsyah and Sri Herianingrum, Pengaruh Pembiayaan Bank Islam, FDI and Pertumbuhan Ekonomi: Studi Empiris Negara OKI. Jurnal Ilmiah Ekonomi Islam, 2019, Vol. 5 No.3. p. 216.

${ }^{3}$ A. Sarjan, Keuangan Islam Publik: Teori, Praktek and Pengembangannya di Masa Kini. (Watampone: Luqman al-Hakim Press, 2015), p. 9.
} 
bilmaslahah". ${ }^{4}$ Although according to Ibn Taimiyyah the ability to intervene in the economy with the provisions of producers offering goods is too high. ${ }^{5}$

In the previous several centuries many economic thinkers have contributed to the economy, both from the Western and Islamic world. However, perhaps there is still not much known that the economic thoughts of the Muslim community came much earlier than the economic thoughts of the Western world. One of them is the economic thinking of Abu Yusuf. His most phenomenal thinking is about the principles (canons) of taxation.

Relevant to current conditions, taxes become the largest source of income in a country. Abu Yusuf as a reformer figure has demonstrated a tax concept that is somewhat unique. It was written in his very famous book, Al-kharaj. Even though they named it Al-kharaj, it also explained about other sources of state income such as ghanimah, jiz'yah, usyur, and zakat. Remembering that in modern times various kinds of state financial institutions are non-bank in nature. Like zakat, as a source of Islamic finance that is developing so rapidly, both its management and regulation. Regulations regarding zakat are developed to support orderly management of zakat. ${ }^{6}$

Regarding taxes, Abu Yusuf made a new formulation in tax and excise matters. The thought of Abu Yusuf makes it interesting to discuss, remembering the book of al-kharaj was written as the request of the caliph Harun al-Rashid. The book will be used as a guideline in collecting state revenue and as a reference in managing state finances. The most memorable thing from the thought of Abu Yusuf is that in realizing the goals of a country, one that must sustain is the economy.

This study will specifically examine the economic thinking of Abu Yusuf in terms of Islamic public financial management. Abu Yusuf's thoughts became interesting things known gradually, considering his thoughts were categorized as a renewal in Islamic law in the economic field. It was based on the importance of a reference in managing a country's finances so that a balance could occur in economic fundamentals. For example, in Indonesia, public financial management such as tax sometimes becomes a problem that is still difficult to solve, for this study will present the financial management system on an Islamic basis through the thought of Abu Yusuf.

${ }^{4}$ Lukman Arake, Otoritas Kepala Negara dalam Menentukan Suatu Kebijakan Perspektif Siyasah Syar'iyah. Al-Bayyinah, Vol. 3 No. 2 (2019), p. 174.

${ }^{5}$ Nurul Huda, Telaah kritis pemikiran Abu Yusuf tentang larangan intervensi pemerintah dalam menetapkan harga (Doctoral dissertation, IAIN Walisongo, 2014). p. 62.

${ }^{6}$ Asmawati, Progresif Sumber Keuangan Islam di Era Klasik and Modern, Al-Bayyinah, Vol. 3, No. 2, (2009), p. 213. 


\section{DISCUSSION}

\section{A. Islamic Public Finance based in Al-kharaj Perspectives}

Al-kharaj as the title of Abu Yusuf's book has a broader meaning than just one source of state revenue. Al-kharaj for Abu Yusuf has a special and general meaning. In the context of the title, it means that he meant Kharaj with a general meaning, namely several sources of state revenue which included ghanimah, jiz'yah, usyur trade, and alms. This was confirmed by a scholar named DhiyauddinAr-Rais, that the use of the word Al-kharaj was originally for a more general meaning, the special meaning of the word Al-kharaj came in the fuqaha period after Abu Yusuf. ${ }^{7}$ The division of public finances based on the book of Al-kharaj in the thought of Abu Yusuf is included in the taxation, booty and customs sections.

\section{Taxation (Al-kharaj)}

Kharaj is a land tax controlled by Muslims both because of war and because the owner entered into a peace agreement with Muslim forces. They remain the rightful owners of their lands but by paying a certain amount of tax (kharaj) to Baitul Maal. ${ }^{8}$ Abu Yusuf's idea of this land tax is based on the history of the caliph Umar bin Khatab, during which he imposed a tax on land. It aims to finance the state budget. In addition, also to encourage the enthusiasm of Muslim soldiers in jihad and guarding the border region. Allocation of taxes in various types of land accompanied by the amount of tax that must be paid.

\begin{tabular}{lcccc}
\hline \multicolumn{1}{c}{ Land } & $\begin{array}{c}\text { Tax:Natural } \\
\text { Irrigation }\end{array}$ & $\begin{array}{c}\text { Tax: tool- } \\
\text { helpedIrrigation }\end{array}$ & Summer & $\begin{array}{c}\text { Other } \\
\text { Seasons }\end{array}$ \\
\hline Wheat and similar & $2 / 5$ & $1,5 / 5$ & - & - \\
\hline $\begin{array}{l}\text { Dates, grapes, } \\
\text { ruthabandother } \\
\text { plantation products }\end{array}$ & & & $1 / 4$ & $1 / 3$ \\
\hline
\end{tabular}

\section{Ghanimah (war booty)}

Booty is a consequence of the enemy defeat in a holy war (سبيل اله (سبل). The provision of the war booty is based on the revelation of the Qur'an. ${ }^{9}$ The verse that explains the law of booty is The Holy Qur'an Surah Al-Anfaal/8: 41.

\section{${ }^{7}$ Nurul Huda and Ahmad Muti. Keuangan, p. 71.}

${ }^{8}$ Nur Chamid. Jejak Langkah Sejarah PemikiranEkonomi Islam (1 ${ }^{\text {st }}$ Ed.; Yogyakarta: Pustaka Pelajar, 2010), p. 160.

${ }^{9}$ A. Sarjan, Keuangan, p. 26. 


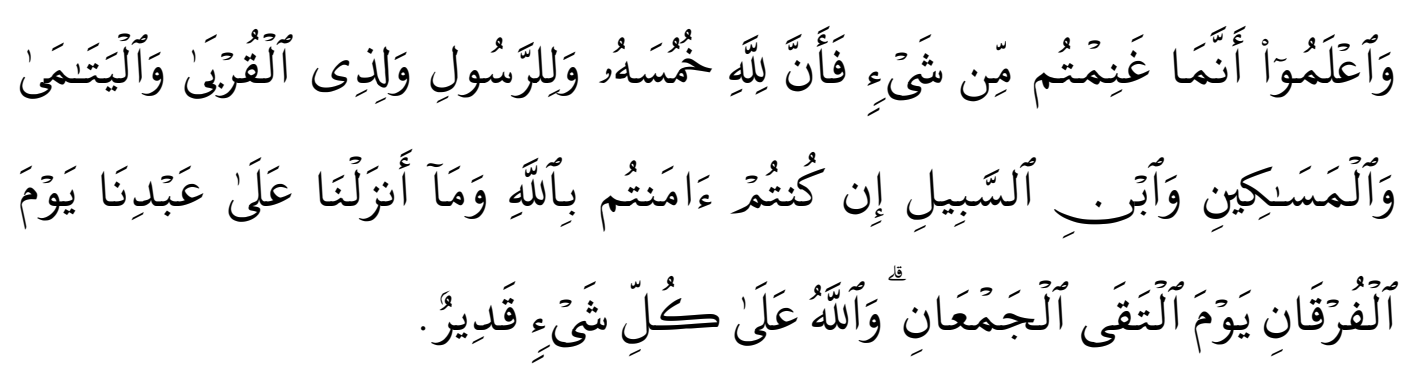

Translation:

And know that anything you obtain of war booty - then indeed, for Allah is one fifth of it and for the Messenger and for (his) near relatives and the orphans, the needy, and the (stranded) traveler, if you have believed in Allah and in that which We sent down to Our Servant on the day of criterion - the day when the two armies met. And Allah, over all things, is competent. $^{10}$

According to Abu Yusuf's perspective, ghanimah is not only a form of war booty, but also includes mines ( $m a^{\prime}$ din) and jewelry obtained from the sea, as well as found items or treasure (rikaz). Storage of mining goods can be divided into two, namely zakat and ghanimah posts. The zakat post includes mining items which amount to 20 gold coins and 200 silver dirhams. While the ghanimah post includes mining goods which do not reach 20 gold coins or 200 silver dirhams. While the tax imposed on rikaz is $1 / 5$, both for Muslims and dzimmi non-muslims. As for kharbinon-muslims, he is obliged to surrender these assets to the Islamic government. Like ghanimah, marine wealth is also taxed $1 / 5$, as Abu Yusuf wrote in his book.

$$
\text { و وسألت يا أمير تامؤمنين عما يخرج من حلية و عنبر ، فإن فيما يخرج من البحر من الحلية } 11 \text { الخمبة }
$$

Meaning;

O AmurulMukminin, you ask about assets that come out of the sea in the form of jewelery and gems, in fact jewelry and gems that come out of the sea are taxed $1 / 5$.

\section{Usyur}

In Bek's note, it is explained that the rules regarding usyur, or what is now better known as customs, are not actually listed in the Qur'an. This was first applied at the time of Umar bin Khatab, the reason being that Abu Musa Al-Ash'ari wrote a letter to him telling him that traders of the Muslims who came to the kharbi non-

10 al-Mehri, A. B. (Ed.). The Qur'ān: With Sürah Introductions and Appendices: Saheeh International Translation (Maktabah Booksellers and Publishers, 2010), p. 246.

${ }^{11}$ Abu Yusuf Ya'qub bin Ibrahim. Kitabul Kharaj: Lilqaadhi Abu Yusuf Ya'qub bin Ibrahim(Beirut: Daarul Ma'rifah, 1979), p. 70. 
muslims region were subject to usyur $(1 / 10)$. Umar ordered that he also take the same amount of tax from them, and dzimmah non-muslim 5\% and from the Muslims 2.5\% with a minimum limit of the amount of merchandise reached 200 dirhams. ${ }^{12}$ Then the regulation was continued by Abu Yusuf. He wrote about the terms of the following usyur.

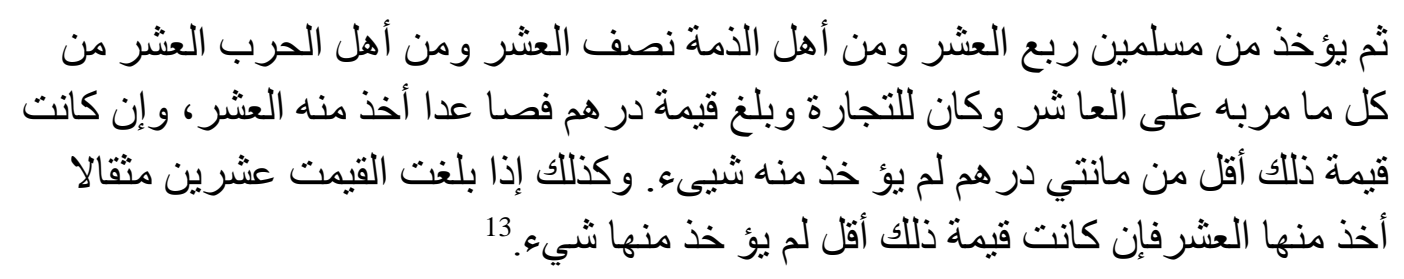

Meaning:

Then taken from Muslim traders 2.5\%, from dzimmah non-muslims 5\% and from kharbi non-muslims (who fight Islam) 10\%, for those who cross customs posts with the intention to trade, and the trade value reaches 200 dirhams or more, if the value did not reach 200 dirhams so nothing was charged.

4. Jiz'yah

Jiz'yah is a head tax for non-Muslims who enter the territory and protect the Islamic government, because they do not participate in fighting with Muslims in the fight against enemies, and if non-Muslims join in the fight to help Muslims fight the enemy, according to Bek (1970: 150), they are not subject to jiz'yah, because they help protect the country. ${ }^{14}$

Jiz'yah is only required for men, not for women and children. This tax also does not apply to poor people from the mustahik group, blind people who do not have work and retired groups. This tax rate is adjusted to the level of the people's economy.

(a) River and water sector

The management of an empty island (without a legal owner) is allowed by the government but must first go through a permit and the government has the right to obtain tax from the use of the land. The status of this empty island is the same as dead land (idle assets). In the water and river sector, Abu Yusuf explained that management must be professional so that it can be optimally utilized by

\footnotetext{
${ }^{12}$ Nurul Huda and Ahmad Muti. Keuangan, p. 91.

${ }^{13} \mathrm{Abu}$ Yusuf Ya'qub bin Ibrahim. Kitabul, p. 132-133.

${ }^{14}$ Nurul Huda and Ahmad Muti. Keuangan, p. 101.
} 
Muslims. It also said that drinking water and irrigation water management must be differentiated. Because if not, this can cause pollution.

To improve public welfare and ensure full utilization of resources, Abu Yusuf believes that natural resources such as water, grass, etc. should not be limited to certain individuals, but must be provided free to all. He quoted a hadith of the Prophet stating, "after being used for your needs, let the water flow into your neighbor, starting from the closest neighbor"15

In addition, according to Abu Yusuf, when an IbnuSabil crossed a well, the owner does not have right to forbid it or sell it. According to him, water that can be traded is water that is in packages or special places. This is because he relied on the hadith narrated by Ibn Hibban:

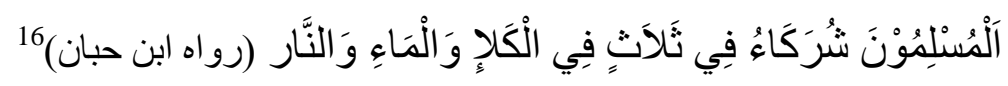

Meaning:

The Muslims united in three ways, namely the meadow, water and fire (hadith narrated by Ibn Hibban)

(b) The field of productive assets

1) Qatha'i, namely land granted by the government to the people who have a big share in a country.

2) MawatulArdh, is land that has never been managed by anyone. Management of this dead land is allowed with government permission. However, if it is not managed for three years, the government has the right to take it back. This was revealed by Abu Yusuf in Al-kharaj.

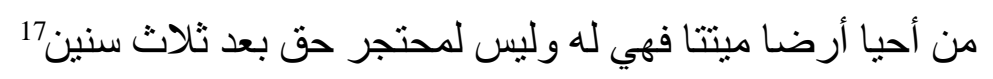

Meaning:

Whoever revives the dead land, then he has the right to manage it, and the person who fences the land no longer has the right to the land after

Abu Yusuf's perspective in measuring the types and status of land. Land is categorized as an economic resource, so the determination of land type and status is considered urgent by Abu Yusuf.

15 Adiwarman AzwarKarim.Sejarah Pemikiran Ekonomi Islam(3 $3^{\text {rd }}$ Ed.; Jakarta: PT RajaGrafindo Persada, 2008), p. 240.

${ }^{16}$ Nurul Huda and Ahmad Muti. Keuangan, p. 105.

${ }^{17}$ Abu Yusuf Ya'qub bin Ibrahim. Kitabul, p. 65. 
Land Type and Status based on Abu Yusuf's Perspective ${ }^{18}$

\begin{tabular}{|c|c|}
\hline Land Type & Land Status \\
\hline Arabian peninsula land & Usyriyyahland \\
\hline $\begin{array}{l}\text { Non-Arabian Peninsula land: } \\
\text { 1. Conquered Land } \\
\text { 1.1 Countries who have lost the war } \\
\text { embraced Islam } \\
\text { 1.2 Not distributed } \\
\text { 1.3 Distributed to the soldiers } \\
\text { 1.4 State owned } \\
1.4 .1 \text { Qatha'i } \\
1.4 .2 \text { Dead land } \\
\text { 2. Land under a peace agreement (ardh shulh) } \\
\text { 2.1 residents converted to Islam } \\
\text { 2.2 residents do not convert to Islam } \\
\text { 3. Muslim land }\end{array}$ & $\begin{array}{l}\text { 1.1 Usyriyyahland } \\
\text { 1.2 Kharajiyyah tanah (applies } \\
\text { to all landowners both } \\
\text { Muslim and dzimmi) } \\
\text { 1.3 Usyriyyahland } \\
\text { 1.4 Usyriyyah land (if it is } \\
\text { managedby Muslim and } \\
\text { not in the Kharajiyyah } \\
\text { land) or the Kharajiyyah } \\
\text { land if it is } \\
\text { managedbydzimmi both in } \\
\text { the usyriyyah land and } \\
\text { kharajiyyah... } \\
\text { 1.1 Usyriyyahland } \\
\text { 1.2 Kharajiyyahland } \\
\text { 2. Usyriyyahland }\end{array}$ \\
\hline
\end{tabular}

(c) Zakat Section

As one of the country's financial instruments, zakat remains one of the sources of state finance at the time. However, he did not discuss in detail about the laws of zakat commonly practiced by fiqh scholars. He only explained globally. His description on the issue of zakat often touches on the issue of justice in general. ${ }^{19}$ Zakat recipients have certain criteria such as those contained in The Holy Qur'an Surah At-Taubah (9): 60.

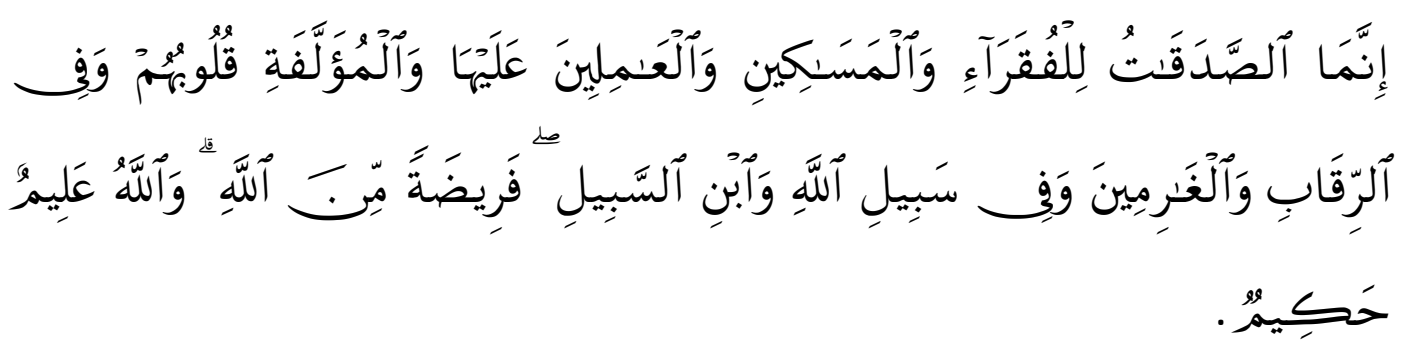

\footnotetext{
${ }^{18}$ Nurul Huda and Ahmad Muti. Keuangan, p. 109.

${ }^{19}$ Nur Chamid. Jejak, p. 158.
} 
The translation:

Zakat expenditures are only for the poor and for the needy and for those employed to collect (zakat) and for bringing hearts together (for Islam) and for freeing captives (or slaves) and for those in debt and for the cause of Allah and for the (stranded) traveler - an obligation (imposed) by Allah. And Allah is Knowing and Wise. ${ }^{20}$

Zakat in the understanding of Abu Yusuf has divided into three parts of zakat. First, Abu Yusuf understands zakat on agriculture which has certain measurements, as stated in the Al-kharaj book.

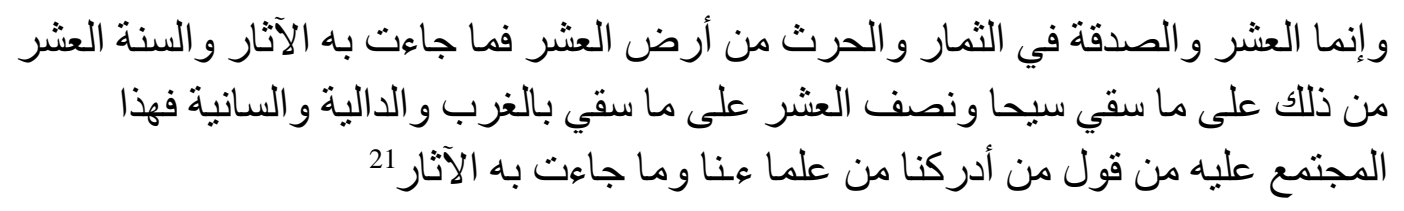

Meaning:

Usyur and zakat only apply to fruits and agricultural products originating from usyur land with provisions that must be issued 1/10 (10\%) if the irrigation is natural according to atsar and hadith statements, and $5 \%$ if the irrigation requires funds, this is the ijma' of our scholars and as stated in the atsar.

Nisab of zakat on agriculture is five wasaq, but if the agricultural output is not up to five wasaq, then it is not mandatory to be zakati. This is according to the hadith of the Prophet sallallaahu 'alaihiwasallam

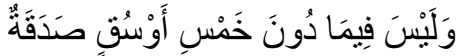
Meaning: There is no zakat for plants under 5 wasaq. Wasaq is the same as 60 sha'. So, five wasaq is equal to 300 sha', as explained by Abu Yusuf:

\section{و الوسق ستون صاعا بصا ع النبي صلى الله عليه وسلم فا لخمسة أوسق ثلاثماءة صاع:22}

Meaning:

Wasaq is equal to Prophet's sixty sha', then five wasaq is equal to three hundred sha'.

Secondly, zakat on trade, Abu Yusuf classified zakat on trade into customs. Abu Yusuf's notes on zakat on trade included in customs posts. That thought was outlined in an explanation of the trader who was giving his zakat. Abu Yusuf explained that:

$$
\text { و وإذا مر التاجر علنالعا شر بمال أو بمتاع وقال قد أديت زكاته وحلف على ذلك فإن ذلك يقبل }
$$

${ }^{20}$ Al-Mehri, A. B. (Ed.). The Qur'ān, p. 264.

${ }^{21} \mathrm{Abu}$ Yusuf Ya'qub bin Ibrahim. Kitabul, p. 51.

${ }^{22}$ Abu Yusuf Ya'qub bin Ibrahim. Kitabul, p. 53.

${ }^{23} \mathrm{Abu}$ Yusuf Ya'qub bin Ibrahim. Kitabul, p. 134. 
Meaning:

If a trader (Muslim) crosses the customs post carrying property and merchandise, then says: I have fulfilled the zakat by swearing, then the oath is accepted, and fall for him usyur.

Abu Yusuf's understanding of zakat on trade is based on the obligation to fulfill zakat on trade. Abu Yusuf in determining zakat on trade is based on the word of Allah in the The Holy Qur'an Surah al-Baqarah (2): 267.

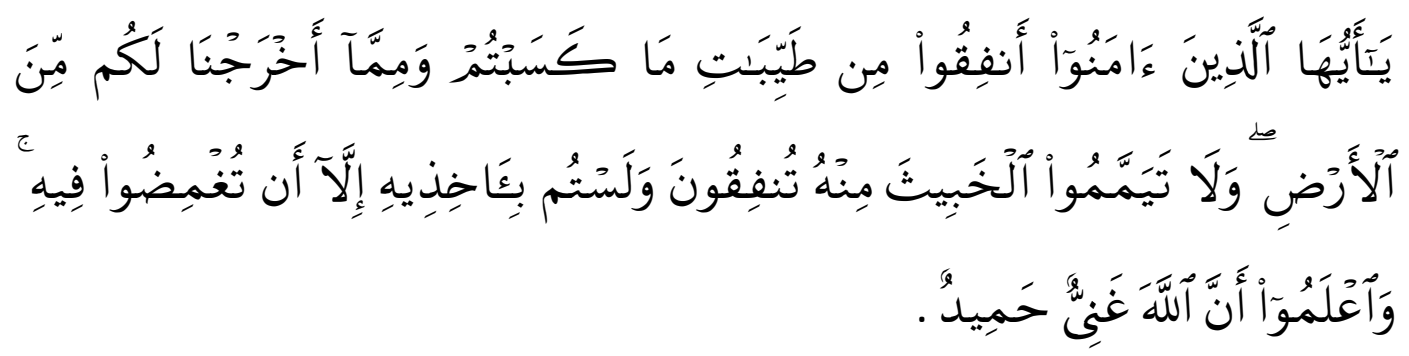

The translation:

O you who have believed, spend from the good things which you have earned and from that which We have produced for you from the earth. And do not aim toward the defective therefrom, spending (from that) while you would not take it (yourself) except with closed eyes. And know that Allah is Free of need and Praiseworthy. ${ }^{24}$

Third, zakat on livestock, like other zakat, Abu Yusuf always advised the Caliph Harun to order officials to collect zakat based on the provisions of the text. Livestock that must be treated include goats, cows or buffaloes, horses and camels. The table below shows the threshold of the animals that must be distributed zakat. Nishab of Zakat on livestock as explained by Abu Yusuf by dividing the types of liveestocks that are paid zakat for, their nishab and the amount of zakat. ${ }^{25}$

Table. Nishab of Zakat on livestock based on Abu Yusuf's version

\begin{tabular}{lll}
\hline \multicolumn{1}{c}{ Types of livestocks } & \multicolumn{1}{c}{ Nishab } & \multicolumn{1}{c}{ Amount of Zakat } \\
\hline Goat & 40-120 heads & 1 head \\
\cline { 2 - 3 } & 121-200 heads & 2 heads \\
\cline { 2 - 3 } & 201-300 heads & 3 heads \\
\cline { 2 - 3 } & 301-400 heads & 4 heads \\
\hline Note: then every one-hundred heads of goats, the zakat plus one head of goat \\
\hline Cow and Buffalo & 30 heads & 1 tabi' \\
\cline { 2 - 3 } & 40 heads & 1 musinnah \\
\hline
\end{tabular}

${ }^{24}$ Al-Mehri, A. B. (Ed.). The Qur'ān, p. 56.

${ }^{25}$ Nurul Huda and Ahmad Muti. Keuangan, p. 118. 


\begin{tabular}{lll}
\hline Camel & $5-9$ heads & 1 goat \\
\hline $10-14$ heads & 2 goats \\
\hline $15-19$ heads & 3 goats \\
\hline $20-24$ heads & 4 goats \\
\hline $25-35$ heads & 1 bintu makhadhcamel \\
\hline $36-45$ heads & 1 bintu labuncamel \\
\hline $46-60$ heads & 1 hiqqohcamel \\
\hline $61-75$ heads & 1 Jaza'ahcamel \\
\hline $76-90$ heads & 2 bintu labuncamels \\
\hline $91-120$ heads & 2 hiqqohcamels
\end{tabular}

Note: if above that amount then every 50 heads, the zakat is 1 hiqqoh camel and every 40 heads, the zakat is bintu labun camel

Based on the description above, the source of state revenue is based on the view of Abu Yusuf in Al-kharaj by categorizing the types of income in the form of fixed and non-permanent income. Forms of income, types of income and zakat storage posts. Abu Yusuf gives a detailed understanding of what is included in state revenue. $^{26}$

Table. State Revenue Structure based on Abu Yusuf's Perspective

\begin{tabular}{|c|c|c|c|}
\hline $\begin{array}{l}\text { Types } \\
\text { ofIncom } \\
\text { e }\end{array}$ & Forms ofIncome & Kinds ofIncome & Storage Post \\
\hline \multirow[t]{5}{*}{$\begin{array}{l}\text { Fixed } \\
\text { Income }\end{array}$} & Zakat & $\begin{array}{l}\text { Zakat on livestock, zakat } \\
\text { on agriculture, zakat on } \\
\text { trade }\end{array}$ & Zakat \\
\hline & Kharaj & Zakat on agriculture & Kharaj and jiz'yah \\
\hline & Jiz'yah & $\begin{array}{l}\text { Taxon head for non- } \\
\text { Muslims who are protected } \\
\text { by an Islamic state }\end{array}$ & Kharaj and jiz'yah \\
\hline & $\begin{array}{l}\text { Public Ownership } \\
\text { Section }\end{array}$ & $\begin{array}{l}\text { Waters and rivers, state- } \\
\text { owned assets, including: } \\
\text { agricultural land (Qatha'i), } \\
\text { dead land (Mawatul ardh) }\end{array}$ & Kharaj and jiz'yah \\
\hline & Usyur (Customs) & $\begin{array}{l}\text { Customs tax applies to } \\
\text { non-Muslim traders, and } \\
\text { Muslims are required to } \\
\text { pay only if they have not }\end{array}$ & Kharaj and jiz'yah \\
\hline
\end{tabular}

${ }^{26}$ Nurul Huda and Ahmad Muti. Keuangan, p. 119. 


\begin{tabular}{|c|c|c|c|}
\hline & & paid the zakat on trade & \\
\hline $\begin{array}{l}\text { Non- } \\
\text { permane } \\
\text { nt } \\
\text { Income }\end{array}$ & Ghanimah & $\begin{array}{l}\text { War booty, sea wealth, } \\
\text { minerals and rikaz whose } \\
\text { value is not up to } 200 \\
\text { silver dirhams or } 20 \text { gold } \\
\text { mitsqals }\end{array}$ & $\begin{array}{l}\text { Ghanimah, if } 20 \\
\text { mitsqol or } 200 \\
\text { dirhams, } \\
\text { including zakat }\end{array}$ \\
\hline
\end{tabular}

\section{B. Abu Yusuf's Economic Policy}

Abu Yusuf Ya'qub Ibrahim is a judge and a friend of Abu Hanifa. He is known for his excavation of the position of al-qadhi (judge) and his attention to public finances, the role of the state, public works, and agricultural development. ${ }^{27} \mathrm{He}$ also has a high level of observation and analysis so that he is able to overcome the various economic problems in his country.

The economic thought of Abu Yusuf prioritizes the concept of the benefit of the Ummah. The size of the problem, according to Abu Yusuf can be measured from several aspects, namely balance (tawazun), free will (al-ikhtikar), responsibility/justice (al-alahadalah)/(accountability), and doing good (al-ikhsan). With this vision of welfare (maslahah), Abu Yusuf can make a major contribution to the prosperity and justice of economic stability in the golden age of Islam/Abbasid dynasty (Harun al-Rashid's period). ${ }^{28}$

As we all know that at the time of the Caliph Harun al-Rashid the open economic system was in effect, which formulation was as follows:

$$
Y=C+(Z+T a x)+I+G+(X-M)
$$

Information: $\mathrm{Y}=$ income; $\mathrm{C}=$ consumption; $\mathrm{Z}=$ zakat; Tax = Tax; $\mathrm{I}=$ investment; $\mathrm{G}=$ government; $\mathrm{X}=$ export; $\mathrm{M}=$ import.

During the era of caliph Harun al-Rashid, the economy was developing rapidly. Trade is carried out both within the Islamic state itself and between other countries. It aims to open up greater business opportunities for Muslims as well as in anticipation of a crisis of basic needs. The scheme below shows one of the expansions in the caliph Harun al-Rashid.

${ }^{27}$ Juhaya S Pradja. Ekonomi Syariah (1t Ed.; Bandung: CV. Pustaka Setia, 2012), p. 44.

${ }^{28} \mathrm{Nurul} \mathrm{Huda}$ and Ahmad Muti. Keuangan, p. 65. 


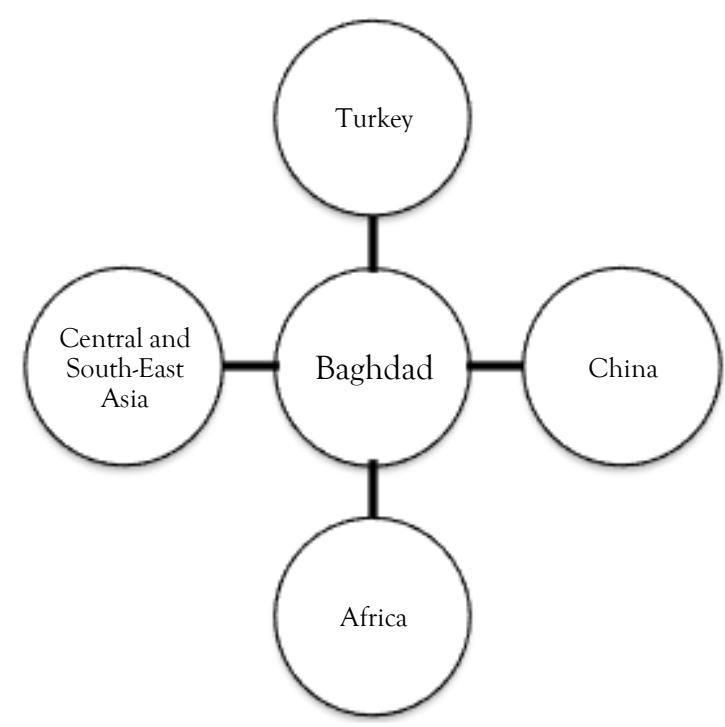

At that time Baghdad carried out cooperation in the economic fields with several regions from various parts of the world, such as China, Africa, Central Asia, Southeast Asia and Turkey. As Abu Yusuf's perspective prioritizes flexibility in trading. Cooperation can be carried out between various regions, both areas where the majority of the population is Muslim or non-Muslim.

The main strength of Abu Yusuf's thought is in public finance matters. Apart from the principles of taxation and the responsibility of the Islamic state for the welfare of its people, he gave several suggestions on ways to obtain expenditure resources for long-term development, such as building bridges and dams as well as digging large and small channels. ${ }^{29}$ Broadly speaking, the economic thought of Abu Yusuf can be described as follows.

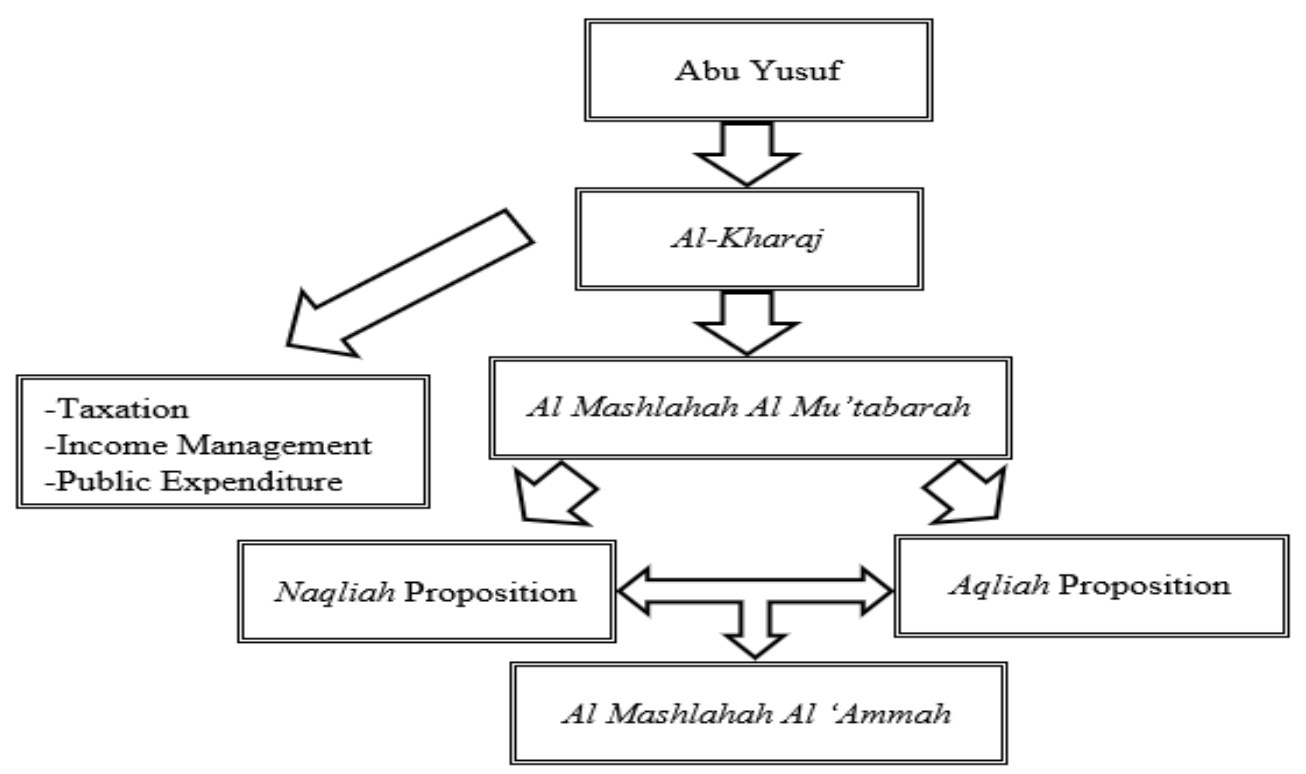

${ }^{29}$ Adiwarman AzwarKarim.Sejarah, p. 16. 
The agendas launched by Abu Yusuf are:

(1) Replacing the wazifah system with the Muqasamah system

The term wazifah and muqasamah are terms to refer to the tax collection system. Wazifah system is a collection system that is determined based on a fixed value, without distinguishing the size of the ability of the taxpayer or may be able to be confused with the tax collected with the same amount of provisions as a whole. While the muqasamah system is a tax collection system that is imposed based on variable values (changing) taking into account the level of ability and percentage of income or proportional tax.

(2) Building an understanding of social flexibility

In this regard, Abu Yusuf responded to the treatment of three groups that were deemed not to have full legal capacity, namely the Kharbi group, the Musta'min group, and the Dzimmis group. Abu Yusuf tried to give an understanding of the balance and equality of rights towards them in his community by regulating several specific provisions relating to citizenship status, the economic and trade system and other legal provisions.

(3) Building a transparent economic system and politics

Transparency built by Abu Yusuf is seen when he describes state income which includes ghanimah and fay' as income which is incidental revenue, while kharaj, jiz'yah, Usyur, and Sadaqah/zakat as income which is permanent revenue.

Abu Yusuf strongly opposed the agricultural tax. He suggested that tax officials be given a salary and their behavior must always be monitored to prevent corruption and oppressive practices. ${ }^{30}$ State expenditures according to Abu Yusuf include personnel expenditure, military defense (u'thoyatuljunud), fulfillment of basic needs of the people (minimum level of living), infrastructure projects and mustahik of zakat.

When talking about the provision of infrastructure facilities, Abu Yusuf stated that the state is responsible for fulfilling it in order to increase land productivity, people's prosperity and economic growth. He argues that all costs needed for the procurement of public projects, such as the construction of walls, and dams, must be borne by the state. ${ }^{31}$ For more details, the following table is presented on the structure of State Budget (APBN) expenditure according to Abu Yusuf.

\footnotetext{
${ }^{30}$ Adiwarman AzwarKarim.Sejarah, p. 15.

${ }^{31}$ Adiwarman AzwarKarim.Sejarah, p. 236.
} 
Structure of State Budget Spending according to Abu Yusuf (Expenditure) ${ }^{32}$

\begin{tabular}{ll}
\hline \multicolumn{1}{c}{ Kindsof Expenditure } & \multicolumn{1}{c}{ Formsof Expenditure } \\
\hline SpecialSpending & $\begin{array}{l}\text { Mustahikof zakat and spending from } \\
\text { special assets and ghanimah (military) as } \\
\text { well as fulfillment of the minimum needs } \\
\text { of the citizens. }\end{array}$ \\
\hline RegularSpending & Routine government operations include \\
& salaries for government employees and \\
& infrastructure development. \\
\hline
\end{tabular}

\section{Contextualization of Al-kharaj's inEconomic Reality}

Aside from being an instrument for regulating state expenditure and revenue, the state budgets also has a very urgent function, namely in terms of overseeing public financial management in order to create stability in the economy. Other functions namely for authorization, allocation and distribution. Creating stability in the economy requires good cooperation in various elements. Because the lack of cooperation between various parties in the government can cause various problems, including a crisis of ethical and moral values of justice that leads to instability in the economic system, a culture of corruption, the luxurious life of the rulers, and a culture of adoration for the court, and even worse the exploitation religion for the personal benefit of the authorities.

The big problem facing the country, in Abu Yusuf's view, must be solved by putting forward the value of the balance between output and input. To achieve the intended balance, according to Abu Yusuf, government and citizens ethics need to be addressed. Because economic stability can only be achieved if the citizens and the government finally arrive at a coveted economic vision.

(1) Revenue

State revenue from state budget (APBN) perspective is not much different from Al-kharaj perspective, state revenue from oil and gas is classified by Abu Yusuf into ghanimah which if managed by the private sector, the tax is as much as $1 / 5$ paid to the state. ${ }^{33}$ Land and building tax (PBB) is almost the same as kharaj. However, the difference lies in the object. PBB is applied to all types of land, both agricultural land, buildings and others. While kharaj, is only imposed on agricultural land. In addition, the taxpayers kharaj namely the unbelievers.

Regarding the collection system, kharaj uses a system in which the state determines tax collection. While what applies in Indonesia is a self-assessment system that is the taxpayer who calculates and reports the tax. The use of the system

\footnotetext{
${ }^{32}$ Nurul Huda and Ahmad Muti. Keuangan, p. 131.

${ }^{33}$ Nurul Huda and Ahmad Muti. Keuangan, p. 139.
} 
can lead to new polemics, such as the manipulation of tax calculations and extortion of tax officials.

However, back again to the morals of each individual. If his morale is good, then of course he will fulfill his obligations as a taxpayer or tax official.

Customs also have similarities with usyur, that is, applied to commercial goods and paid at the border post. The difference is that customs applies to all religions. Whereas usyur, the tariff is different for each religion. In addition, the usyur tax is calculated with a certain size, which is a minimum limit of 200 dirhams. As with customs, it is taken from the nominal basis of some goods with the standards of other goods.

Meanwhile, mining goods in the Indonesian State Budget impose a landrent and royalty system. While in Al-kharaj, it is subject to $1 / 5$ and that too after going through processing. The minimum limit is 20 gold misqals and zakat property. Regarding marine wealth, in Indonesia the emphasis is on the fisheries sector. Unlike the concept of Al-kharaj which focuses on jewelery and so on.

(2) Expenditures (expenditure)

State expenditure referred to here is personnel expenditure, military defense expenditure and infrastructure development. In Indonesia, personnel expenditure has a very large influence on the state budget. Payment of employee salaries is determined by the number of employees and salary levels. Like civil servants, the salary is determined based on class. The higher the class, the greater the salary received.

While in Al-kharaj, it is not only the salary of employees. However, all matters relating to public services, there are people's rights in it. Such as education, health, drinking water, lighting, and other forms of service. From a military standpoint, Indonesian National Army (TNI) and Indonesian Republic Police (POLRI) salaries in Indonesia are taken from personnel expenditure. While Alkharaj, the budget allocation came from ghanimah (booty) of 4/5 parts.

In relation to state expenditure, there is still an important issue, namely government investment in the form of infrastructure development. There are at least three fundamental issues that need attention: first, how projects from government investment are appraised. Second, is the overall program of government investment consistent or in accordance with macroeconomic conditions and institutional capacity. Third, how the problems faced in preparing the government investment program can be overcome. ${ }^{34}$

${ }^{34}$ Nurul Huda and Ahmad Muti. Keuangan, p. 151. 
The table below shows a comparison of the perspective of the State Budget of Abu Yusuf and the Indonesian State Budget. ${ }^{35}$

\begin{tabular}{cccc}
\hline \multicolumn{2}{c}{ Revenue } & \multicolumn{2}{c}{ Expenditure } \\
\hline $\begin{array}{c}\text { Not Included in } \\
\text { Al-kharaj }\end{array}$ & $\begin{array}{c}\text { Not Included in } \\
\text { Indonesian State } \\
\text { Budget }\end{array}$ & $\begin{array}{c}\text { Not Included in } \\
\text { Al-kharaj }\end{array}$ & $\begin{array}{c}\text { Not Included in } \\
\text { Indonesian State } \\
\text { Budget }\end{array}$ \\
\hline $\begin{array}{c}\text { Income Tax }(\mathrm{PPh}) \\
\text { Value Added Tax } \\
\text { (VAT)/PPN }\end{array}$ & Jiz'yah & $\begin{array}{c}\text { Interest and } \\
\text { foreign debt } \\
\text { installments }\end{array}$ & $\begin{array}{c}\text { Fulfillment of } \\
\text { basic needs of } \\
\text { citizens }\end{array}$ \\
\hline Oil and gas & War Booty & Subsidi & Mustahik of zakat \\
\hline Export Tax & & & \\
\hline
\end{tabular}

\section{CONCLUSION}

The main concept in the economic thought of Abu Yusuf is to prioritize the benefit of the Ummah. In the management of public finances, both those related to revenue and expenditure, the government must consider the benefit of its people. The people have the right to all public services. Maslahah size, according to him, can be measured from several aspects, namely balance (tawazun), free will (alikhtikar), responsibility/justice (al-alahadalah)/(accountability), and doing good (alikhsan).

In terms of state revenue, the perspective of the APBN in force in Indonesia is not much different from the perspective of Al-kharaj. In Indonesia, state expenditure is strongly supported by sources of tax revenue. This can be seen from the increasingly large contribution of taxes to sources of funding for state expenditure. But all that also depends on its management. Tax collection must be done on the principle of fairness. Criteria of tax employees must also be considered. The government must also contribute to the supervision of public financial management. Or in other words, checks and balances between the government and related institutions need to be applied.

${ }^{35}$ Nurul Huda and Ahmad Muti. Keuangan, p. 152. 


\section{REFERENCES}

Abu Yusuf Ya'qub bin Ibrahim. Kitabul Kharaj: Lilqaadhi Abu Yusuf Ya'qub bin Ibrahim. Beirut: Daarul Ma'rifah, 1979.

Asmawati, A. (2019). PROGRESIF SUMBER KEUANGAN ISLAM DI ERA KLASIK DAN MODERN. Al-Bayyinah, 3(2), 204-219.

Arake, L. (2019). OTORITAS KEPALA NEGARA DALAM MENENTUKAN SUATU KEBIJAKAN PERSPEKTIF SIYASAH SYAR'IYAH. Al Bayyinah, 3(2), 166-189.

Huda, Nurul. Telaah Kritis Pemikiran Abu Yusuf tentang Larangan Intervensi Pemerintah dalam Menetapkan Harga, Diss. IAIN Walisongo, 2014.

Huda, Nurul dan Ahmad Muti. Keuangan Publik Islami: Pendekatan Al-kharaj (Imam

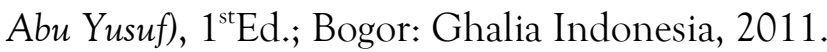

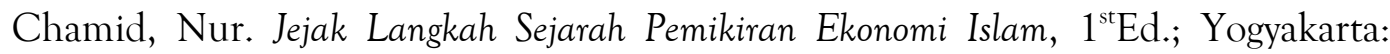
Pustaka Pelajar, 2010.

Karim, Adiwarman Azwar. Sejarah Pemikiran Ekonomi Islam. ${ }^{\text {rd }}{ }^{2}$ d; Jakarta: PT RajaGrafindo Persada, 2008.

al-Mehri, A. B. (Ed.). The Qur'ān: With Sūrah Introductions and Appendices: Saheeh International Translation. Maktabah Booksellers and Publishers, 2010.

Pradja, Juhaya S. Ekonomi Syariah, 1tEd.; Bandung: CV.Pustaka Setia, 2012.

Sarjan, A. Keuangan Islam Publik: Teori, Praktek dan Pengembangannya di Masa Kini. Watampone: Luqman al-Hakim Press, 2015.

Zaimsyah, Annisa Masruri; Herianingrum, Sri. Pengaruh Pembiayaan Bank Islam, FDI dan Pertumbuhan Ekonomi: Studi Empiris Negara OKI. Jurnal Ilmiah Ekonomi Islam, Vol. 5, No. 3, (2019). 